\title{
Fat, Sex, Class, Adaptive Flexibility, and Cultural Change
}

\author{
R. W. Smuts \\ Evolution and Human Behavior Program, Unversity of Michtgan, \\ Michigan
}

\begin{abstract}
In modern industrial nations, the traditional positive correlation between female body fat and social class has turned strongly inverse, thinness in women is admired and plumpness is a handicap. This recent reversal of what had seemed to be stable aspects of human nature is analyzed as a potentially adaptive response to two ecological novelties: chronic food surplus and the breakdown of barriers between men's and women's work, which, together, may have made thinness helpful to women competing for status and resources in both mating and job markets. Whether status and resources still promote long-term Darwinian fitness is an open question. Progress in understanding the unique properties of the human mind depends on widespread recognition that the mind has been designed by natural selection to seek and sometimes find adaptive solutıons to the novel problems we ourselves create. Adaptive flexibility and cultural change are two sides of the same coin.
\end{abstract}

KEY WORDS: Sex differences, Social class, Fatness, Thinness, Adaptatıon, Nutrıtion, Competition, History, Cultural change

he recent history of human fat is an enigma for evolutionists and
historians alıke Women in affluent modern societies are the major
exception to the general rule that body fat correlates positively
with social class In traditional and developing societies around the world, prosperous high-status people are fatter on average than poor low-status people In contemporary industrial nations, however, the correlation between fat and social class has become mixed for men, but strongly and consistently inverse for women (Powdermaker 1960, Goldblatt et al 1965, Brown and Konner 1987, Sobal and Stunkard 1989, Brown 1991, Cassidy 1991)

Although both fatness and social class have been defined and measured in different ways in different studies, the results are overwhelmingly consistent In a comprehensive review of 144 studies published since 1933 on

Received December 31, 1991, revised June 18, 1992

Address reprint requests to R W Smuts, 4011 Thornoaks, Ann Arbor, MI 48104

Ethology and Socioblology $13 \quad 523-542$ (1992)

(C) Elsevier Science Publishıng Co, Inc, 1992

655 Avenue of the Americas, New York. NY 10010

$0162-3095 / 92 / \$ 500$ 
the relationship between status and obesity, Sobal and Stunkard (1989) found not one report of an inverse relationship for either men or women in traditional and developing societies in Africa, Asıa, North and South America. Australia, and the Pacific islands Conversely, they found only one report of a positive relationship between status and obesity for women in the Unted States, Belgıum, Brıtaın. Canada, Czechoslovakıd, Germany, Holland, Israel. New Zealand. Norwdy. and Sweden The one exception was for a sample of ımmıgrants to Belgium

The idealization of female leanness in the United States and other developed nations is a closely related modern anomaly Among the cultures in the Human Relations Area Files with data on some aspect of ideal female body type. 31 out of 38 prefer overall plumpness or moderate fatness (Brown 1991. Anderson et al 1992 count 50 out of 62. see also Cassidy 1991) Nine out of ten societies prefer women with fat hips or legs (Brown 1991 ) Until very recently, western cultures usually concurred The Roman poet Martial wrote in the first century that "the sort of girl I hate is the scrawny one, with arms so thin my rings would fit them. hıps that grate. spıne like a saw, knees like a pin, and a coccyx like a javelın But all the same I don't go in for sheer bulk I appreciate good meat, not blubber on my plate" (Michic 1978, p 169) HLW, a Massachusetts farmer, wrote much the same thing more succinctly and almost as poetically in his mid-nıneteenth century advertisement for a bride with "a form medium sized, well developed, erect, and plump (not gross, but full and round-I do not admire skeletons" (Schwartz 1986, p 59)'

The switch to relative leanness as the norm for middle- and uppei-class women, and to extreme leanness as the ideal, occurred very recently, beginning in the United States near the end of the nineteenth century and gaining momentum ever since, slowly at first and then very rapidly during the past three decades (Brumberg 1988. Schwart 2 1986. Seid 1989)

The first actress to gain national fame as weight control expert was not Jane Fonda or Cher or Kaquel Welch, but Annette Kelleı man, long-distance swimmer turned silent film star, who popularized the form-fitting bathing suit and became the best-known fitness and slimming entrepreneur just before and after World War I In 1918, at 5'33"'. Kellerman weighed 137 pounds Mary Campbell, Miss America in 1922. was a bit slimmer, 5'7" and 140 Needless to say, both were too hedvy by present standards. by 1979, the average Miss America contestant was still 5'7", but weighed only 115 pounds (Brumberg 1988. Seid 1989. Garner et al 1980)

Historian Roberta Seid summarizes the change in standards as the emergence of a "thin preference" after the turn of the century. which became

\footnotetext{
'In addition to the broad trends that are the subject of this paper theie is of couse a great deal of individual and cross-cultural variation in body tatness and preferences See Beller (1977) on individual and cross-culturd tatness differences Ritenbaugh (1991) tor a bitef review of the recent literatule on individual fatness difterences and Anderson et al (1992) toi an evolutionarv analysis of cross-cultural preterence differences
} 
"prejudice" in the 1950s, "myth" in the '60s, "obsession" in the '70s, and "religion" in the '80s (1989, p. Ix) Historian Joan Brumberg also sees a parallel between religion and the slim ideal "Through fastıng, the medieval ascetic strove for perfection in the eyes of her God, the modern anorectic strives for perfection in terms of society's ideal of physical, rather than spiritual, beauty" (1988, p 46)

This paper has two main goals The first is to outline an evolutionary analysis of this recent reversal of what had seemed to be stable aspects of human nature The second is to suggest that such an analysis may help to lluminate current controversies over the adaptiveness of modern human behavior and the limits of adaptive behavioral flexibility (see especially the whole of Ethology and Soctobiology 11(4/5), 1990) In pursuing these goals, I hope to demonstrate as well that historical data can be useful to evolutıonists, and evolutionary analysis, to historians.

\section{THE FUNCTION OF FATNESS}

The essence of evolutionary analysis is the search for function as the ultimate explanation for the traits of organisms The search focuses on understanding how, during the evolutionary history of a species, particular morphological features or behavioral mechanisms were favored by natural selection because they helped individuals to maximize inclusive fitness, that is, to maximize the representation of their own genetic complement in future generatıons (Willams 1966, Hamilton 1964) In operational terms, the search for the function of behavior studies what individuals do to survive, reproduce, and help their relatives to survive and reproduce Behavior that enhances inclusive fitness is said to be adaptive

The historical correlation between social class and human body fat is readıly explained in functional terms as an adaptive response to frequent, universal, and often severe food shortages in preindustrial societies When food is avallable now but may not be avalable later, it pays for those who have access to surplus calories to store the surplus as body fat (Low 1979a,b, Low et al 1987, Brown and Konner 1987) Humans, like other anımals, have therefore evolved a wide variety of physiological and behavioral mechanisms to achieve that result With more food avalable and less physical work to do, the upper classes have more surplus calories to place in the fat bank In the United States, as late as the last quarter of the nıneteenth century, "fat was explicitly equated with money, and the body was described as the bank" (Seld 1989, p 76) ${ }^{2}$

Except for the middle and upper classes in developed societies, women on average are fatter than men The difference begins in childhood, and

\footnotetext{
${ }^{2}$ Beller (1977) and Anderson et al (1992) emphasize that body fat also functions as insulation from cold Anderson et al suggest that fat may be varied in order to control the tımıng of ovulation, this proposed function is discussed brielly below
} 
becomes pronounced during puberty (Balley 1982, Brown and Konner 1987. see Garn et al 1989a,b for the exception) The traditional sex-age pattern of fat deposition reflects the fact that fat is especially valuable to human females of reproductive age because of the high energy costs and long duration of pregnancy, lactation. and infant care Whitıng's (1958) survey of nutritional data from the Human Relations Area Files found that 71 percent of preındustrial societies suffered food shortages in at least one year out of three, and that in 64 percent of societies the shortages that occurred were severe enough to cause substantial weight loss These findings suggest that in most traditional societies, most mothers suffered a serious calorie deficit at least once during the years between conception and weanıng

The idea that plump females are beautiful is easily explained as a reflection of adaptıve male preference for mates whose fatness displays both high status and caloric reserves that can support reproduction when food is scarce (Low et al 1987) Mate choice criteria echo the logic of energy conservation in a world of scarcity, sexual selection reenforces natural selection Mates, however, are not the only ones who have a stake in women's fat stores So do others whose inclusive fitness is affected by women's success as mothers, that is, all their relatives and husbands' relatives as well

\section{THE PUZZLE OF THINNESS}

If human nature evolved under strong selective pressure to strive for and admire fatness, especially in women, then the reversal of these traits in modern industrial societies - the inverse correlation between female fat and social class, the idealization of thin females, the growth of a multı-billion dollar weight-control industry supported maınly by affluent young women-is indeed perplexing

Efforts to reduce weight by dietıng are often overcome, sooner or later, by the ubiquity of high-calorie foods, the prevalence of sedentary life styles and the power of traits designed by natural selection to store surplus calories as fat Brown (1991) observes, however, that 20 million Americans. most of them women, are chronically hungry because they are serious dieters Many women in modern industrial societies appear to be caught in a punishing conflict between powerful evolved mechanısms designed to make them fat. and powerful modern motivations to be slender The high and rising incidence of bulımia and anorexia nervosa during the past 20 years may be the most extreme and puzzling expression of this conflict In the first popular hook on anorexia nervosa. Hilda Bruch described it as an almost unheard of kind of disease, one "that selectively befalls the young, rich and beautiful

the daughters of well-to-do, educated and successful families" (1978, $p$ vii) It 1 all the more puzzling in light of its reported death rate of up to 15 percent of patients in treatment (Brumberg 1988)

The conflict within modern women is reflected in and illuminated by a 
parallel conflict between traditional and modern usage of the words lean and fat In common usage, lean now connotes such desirable qualities as physical fitness, efficiency, health, and strength, while fat connotes excess, ilhess, sluggishness, lack of discipline, and waste A "Dictionary of Cautionary Words and Phrases" compled at the University of Missour School of Journalısm warns reporters to avoid usıng such offensive terms as buxom, matronly, and full-figured, "which themselves are often euphemisms for fat" (Goodman 1991) The modern usages are so new that modern dictionaries preserve the traditional and opposite value associations Derogatory terms are predominant in the Oxford English Dictionary (1989) definitions of lean "wantıng in flesh," "poor or meager in quantity or quality" "innutritıous" "unremuneratıve," "wanting in rich elements or quantitıes," "scantıly furnished, ill provided," "characterized by scarcity " Fat, on the other hand, is defined mainly in terms of desirable qualities. "In well-fed condition," " well-supplied with fat," " "yielding excellent or abundant returns," " fertıle, rich," "well-supplied with what is needful or desırable," "affluent, wealthy," "abundant and plentıful ",

The new derogatory connotations of fat and fatness now have far greater sway in the middle- and upper-class mind than the old dictionary definitions Except in a few traditional arts such as grand opera and sumo wrestling, fatness has become a profound handicap in all areas of social competition, including courtshıp, education, employment, job promotion, earnıngs, politıcs, sports, and even in access to such benefits as desirable housing and good medical care (Cahnman 1968, Brumberg 1988, Seid 1989, Sobal 1991) William Howard Taft, who weighed 355 pounds at his inauguration in 1909 , was the last as well as the fattest of half a dozen fat American presidents (Schwartz 1986) Cecil Fielder, the 270-pound home-run kıng of baseball in 1990 and 1991, was "the slugger nobody wanted" durıng the precedıng seven years of his professional career because managers "saw the heft in his body, not in his stats" (de Jonge 1992)

While fat has become a handicap for men, it is a much greater handicap for women Marriage counselors have found that some women gain weight in order to protect themselves from sexual harassment or the temptation to engage in extramarital relatıonships, some men urge their wives to gain weight in order to insure their wives' fidelity or excuse their own infidelity (Stuart and Jacobson 1987) Whatever the motive, the strategy is based on the assumption that fat women have no sex appeal

There is no shortage of explanatıons for the sudden rise of the thin ideal Much of the literature on the subject has been written by women about women as victims of forces beyond their control Blame has been placed on puritanısm, patriarchy, capitalısm, consumerism, individualısm, the rise of the middle class, and the media, on the fashion, advertising, insurance, health-care, fitness, diet, and weight-loss industries, on mothers, and perhaps most often on "modern society" The thin ideal has been viewed, sometımes by the same author (Szekely 1988 , for example), as an instrument 
men use to derogate and domınate women, and as an effort by women to assert control of their own bodies and destinies The only perceptible consensus is that the origins of the thin ideal are purely social and cultural rather than biological, and owe nothing to evolution Indeed, when biology and deliberate thinness are mentioned in the same context, the context is almost always depicted as a battleground, with human biology fightıng for more fat than modern western culture allows its most-favored members Sobal. for example, refers to the collision between culture and physiology that occurs when "social pressures to become and remain thın" compete with "thrifty genes that store fat" (1991, pp 242-243)

Confidence in the exclusively sociocultural origins of the thin ideal is so taken for granted and so seldom justified that the reasons for its prevalence are difficult to pin down The unstated assumption often seems to be that since biology makes it so hard to lose much weight, something separate and apart from biology must be responsible for the modern desire to get thin

Those who are thinner than they want to be are well aware, however. that biology also makes it hard to gan much weight In fact. of course. biology pushes in both directions Because incapacity, reproductive fallure, and death increase toward both ends of the fat-thın contınuum, humans, like other animals, have evolved mechanısms that usually keep them somewhere in the middle by pushing sometimes more strongly in one direction. sometımes more strongly in the other, but always in both directions We feel hungry when blood sugar is low, satiated when it is high We waste calones by rassing metabolic rate when we gain weight, conserve calories by lowering metabolıc rate when we lose weight The more we gain (or lose) the harder it is to gain (or lose) still more (Beller 1977, Ritenbaugh 1991)

In spite of ideal-weight charts, the best amount of fat to carry is highly variable It is greater for women (especially if they are or are trying to become pregnant), in cold climates and seasons and in societies with fluctuatıng food supplies (Beller 1977, Brown and Konner 1987, Anderson et al 1992) Studies of English and American children rassed in the tropics find that they weigh less than comparable children rassed in England and the United States (Beller 1977) The reason, Beller argues, is that fat is not needed as insulation in tropical climates or as an energy store for those whose food supply is assured She concludes that "the ability to gain and lose werght as the temperature rises and falls, or as granaries wax and wane, is one that has been meticulously bred into the genes of populations living between the climatic extremes of the so-called temperate zones" because of their need "to react with reasonable thermal and economic efficiency to both sets of extremes" (1977, p 290)

The deposition and utilization of body fat respond to a large number of internal and external cues that are processed mainly in the hypothalamus, deep in the unconscious midbrain But the rates at which humans store and use fat are also determined by choices deliberately made in the brain's neocortex about such variables as clothing, shelter, use of fire, place of resi- 
dence, and above all, diet and physical actıvity Girls of marriageable age become even fatter than the hypothalamus would have them because of fattenıng practices embedded in the culture of many traditional societies Conversely, the consistent inverse correlation between fatness and status in first-world women (Sobal and Stunkard 1989) belies the fiction that weightloss programs are always thwarted by the hypothalamtc drive toward female fatness

That choices made unconsciously in the midbrain normally have a b1ological function is taken for granted, but choices made consciously in the neocortex are often thought to lie in the realm of social values and culture, and to be free of biological constraint The neocortex, however, is as much a product of natural selection as the hypothalamus, which means that it evolved because it served the most basic of all biological functions it helped human ancestors to perpetuate their genes

It is, therefore, unreasonable to assume that conscious choices are vulnerable to current social pressures, but immune to the influence of human evolutionary history (Alexander 1987) And it is, therefore, reasonable to suggest that the efforts of modern, high-status first-world women to be thin may be no less rooted in evolved bchavioral mechanisms than the desire of other women, in other times and circumstances, to be fat The fact that the thin ideal has prevalled among upper-status women in spite of the body's strong resistance to large weight losses argues for, rather than against, the biological basis of the new ideal Without a powerful biological component, the forces of cultural change are not likely to have prevalled against powerful biological resistance My aim in the following pages is to begin to identify some specific features of first-world life that may link the emergence of the thin ideal for higher status women to behavioral patterns and mechanısms that evolved because they helped individual ancestral humans to maximize inclusıve fitness

\section{THE FUNCTION OF THINNESS}

The common thread in most of the literature is the recognition that the thin ideal is associated somehow with affluence and economic abundance Brumberg concludes that "today's fastıng girls epitomize the curıous psychic burdens of the dutiful daughters of a people of plenty" (1988, p 271) Schwartz points out that the preference for thinness began in the United States at the very end of the nineteenth century, just when economists Thorstein Veblen and Simon Patten (founder of the American Economic Association) were shiftıng their discipline from the problems of scarcity to the problems of surplus created by the unprecedented increase in the productivity of American industry and agriculture Schwartz argues that "slimmıng is the modern expression of an industrial society confused by its own desires and therefore never satisfied On the one hand, we seen to want more of every- 
thıng, on the other hand, we are suspicious of surplus Increasingly perplexed or intımıdated by abundance, Americans have taken the protocols of slimming as the protocols for social and spiritual renewal" (1986, p 5)

The evolutionary perspective makes it easy to see why modern AmerIcans might well be perplexed or intımıdated by abundance The Malthusian principle that populations tend to outstrip their food supply is the foundation of the Darwinian concept of evolution by natural selection Since humans, like other organısms, were designed by natural selection to cope with scarcity, it is hardly surprising to find them reactıng with ambivalence to their infrequent encounters with chronic surplus During the high middle ages, the growing wealth of monastic orders provoked an ascetic reaction accompanıed by a vogue for relıgıous fastıng, especially by young women (Brumberg 1988) The Embarrassment of Ru hes is the central theme as well as the title of Simon Schama's cultural history (1987) of the golden era of Dutch commercial prosperity in the seventeenth century

It is also easy to see that thinness will not be esteemed when most people are thin, not out of choice but because they are poor and hungry and often sick as well It is not obvious, however, why thinness should be esteemed when most people can be fat because they need not go hungry even if poor

Brown and Konner (1987, p 42) suggest a reason

\begin{abstract}
American ideals of thinness occur in a setting where it is easy to become fat, and preference for plumpness occurs in settings where it is easy to remain lean In context, both standards require the investment of individual effort and economic resources, furthermore, each in its context involves a display of wealth In poor societies the rich impress the poor by becoming fat, which the poor cannot do, in rich societıes even the poor can become fat. and avidly do therefore the rich must impress by staying thin ds if to sdy, "We have so little doubt about where our next meal is coming from. that we don't need a single gram of fat store
\end{abstract}

This is an appealıng scenario to anyone who thinks about social change in Darwinian terms, because the efforts of the rich to impress the poor are directly analogous to the efforts of dominant individuals to intımıdate subordinates that occur in almost all social anımals From this point of view, however, the Brown-Konner scenarıo falls short by fallng to acknowledge that status has a function beyond the symbolic for nch people as for dominant anımals, it is not an end in itself, but a means of enhancing control of valuable resources This shortfall leads directly to another In humans as in most other species, males compete more intensely for status and resources than females do (Daly and Wilson 1983. Trivers 1985), and men usually control most of the wealth and wield most of the power (Low 1990, 1992) If the rich in developed nations are now using thinness to enhance their wealth and power by impressing the poor, then devotion to weight control should be even greater among affluent men than among affluent women That the reverse is true suggests that if thinness is indeed a form of com- 
petitive display, there must be unique ways in which, despite appearances, it serves women's competitive interests better than men's

To say this is not to absolve men of responsibility for the power of the thin ideal over women's lives When the judges of women's success are men, as they usually are, women have to compete by men's standards Shiftıng the focus from men's standards to women's interests is useful, however, because it directs attention to two essential questions With whom are women competing? What are they competing for?

\section{Mating Competition}

In the vast majority of sexual organisms, females are the choosier sex when it comes to mating, and compete with each other for desirable partners (Trivers 1972). This suggests the hypothesis that prosperous women in modern affluent societies are competıng with each other for desırable men by losing weight, just as other women have done and stıll do by gettıng plump The logic behind the hypothesized switch begins with the fact that even in modern affluent America, upwards of ten million poor women are chronically hungry (Physician Task Force on Hunger in America 1985) and many more go hungry involuntarily from time to time In such a society, the poorest women are thın out of hunger, but other lower-class women tend to be on the plump side, and many are obese, perhaps because they have had plenty to eat in the recent past but are not entirely sure they will have enough in the near future In such a society, the best way for a woman to display high status may be to distınguish herself from both groups of social subordinates by combinıng thinness with expensive dress and adornment (Low 1979a)

The strategem outlined here is well exemplified by the career of Mrs Wallis Warfield Simpson and by the observation widely attributed to her that "a woman can never be too rich or too thın "Mrs Simpson might have become Queen of England, but had to settle for Duchess of Windsor after Edward VIII was forced in 1936 to choose between the throne and the slender American who had not yet won her second divorce The slender king-duke, incidentally, was grandson of Edward VII, the last fat Englısh monarch (1901-1910)

The advantage of female thınness in matıng competıtıon has been shown more persuasively by several studies Goldblatt, Moore, and Stunkard (1965) found that in a sample of women lıving in midtown Manhattan in 1954, those who had fallen below the social status of their parents were almost twice as likely to be obese as those who had risen above Since married women were rated on the basis of husband's occupation, it is clear that thinness was associated with advantageous marriage Garn, Sullıvan, and Hawthorne (1989a,b) found that in a sample of married women in Tecumseh, Michigan, who had gone to high school, those who married husbands who had gone to college averaged more than 14 pounds lighter than those who married husbands who had not gone to high school Unfortunately, neither study 
makes it possible to determine whether thinner women married advantageously because they were thinner before marriage, or became thınner after marriage because they married advantageously

When middle- and upper-class women tend to be thinner than other women, whatever the cause, men can afford to prefer thun, well-dressed women with little risk to their own reproductive success because female thınness ingufies control of resources that can sustain fertility at least as reliably as does ample body tat Since hdving a prosperous mate also serves male interests in many other ways, men are then likely to develop a positive preference for thin and prosperous women, which, in turn, improves the mate-choice opportunities of thin women, which reenforces women's motivation to lose weight

This modification of the Brown-Konner hypothesis implies that chronic tood surplus causes an important shift in the selective forces involved in regulatıng fatness When food shortages are severe and frequent, physiology, attitudes, and behavior are governed by the logic of energy conservation women need fat, men prefer fat women, and sexual selection echoes and reenforces natural selection When food scarcity recedes, the logic of energy conscrvation contınues its influence, partly because abundance is unevenly distributed, and partly because evolutionary change occurs slowly For those most favored by abundance, however, the new logic of mate choice and mate attraction diverges from and conflicts with the old logic of energy conservation, and this means that women's desire for much thinner bodies is at constant war with the thrifty aspects of their physiology

This scenario implies that the thin standard of female beauty was not simply imposed on women by culture or by men, that male preference for thın women emerged only when affluent women began to pursue thınness ds a superior mating strategem, and that neither trend could have advanced so far so fast without reenforcement by the other

\section{Career Competition}

Success or fallure in mating competition can have a profound effect on a woman's whole life Nevertheless, for women as for females of other species, competition for desirable mates occupıes a small part of life Much more female time and effort are devoted to ditect competition for economic resources In most anımals, females compete for economic resources, chiefly food, with males as well as with other females Until recently, however, women were almost always restricted to women's work and barred from competition with men for substantial wealth and occupational prestige The emergence of the thin ideal coincided not only with the transition from economic scarcity to economic abundance in the developed world, but also with the emergence of women as high-stakes competitors with each other and with men in work previously reserved for men (Smuts 1959) This suggests the hypothesis that middle- and upper-class women now use thinness as a 
way of competing both with each other and with men for success in professional education, careers, and sometimes politics

There can be no doubt that thınness has become advantageous in the competition for educational and employment success, for men as well as women, but especially for women Naom Wolf (1991) and other femunsts complain that this is the same old story of men judging women, in the job market as in the marriage market, hy their looks While there may he much truth in the story, it overlooks the possibility that female thinness may have become beautiful because it had become a useful measure of female value that serves the interests of both sexes in both markets

The abundant literature on how to acquire the ideal thin female figure and the sales pitch for related products and services often emphasize that success takes effort, time, dedication, and willpower as well as money, and women know how true this is Women's bodies were designed by natural selection to be fatter than men's, losing weight is harder for women than it is for men, and is increasingly difficult with advancing age For a woman more than for a man, therefore, thinness displays the kınd of motivation and life-long persistence that job success demands ${ }^{3}$

In vicw of the stcady decline in idcal femalc weight and the epidemic of anorexia nervosa in recent decades, it is worth noting that as a display of motıvation and determınation, thinness has no clear limit short of disablıng health effects, thinner may always be better Also worth notıng in this same connection is evidence that women want to be even thinner than they thınk men want them to be, and that they thınk men want them to be even thinner than men actually want them to be (Fallon and Rozın 1985 , Polivy et al 1986)

In contrast to women's bodies, men's bodies were designed by natural selection to add muscle in response to hard work For a given weight, men have a more muscle and less fat, and a man who loses weight risks lookıng weaker rather than fitter Indeed, within each sex, fat and muscle tend to go together, contrary to widespread current opınıon (Beller 1977) While most women want to lose weight, most men are satısfied with present weight or want to be heavier in order to look stronger (Fallon and Rozin 1985), an option not open to women because exercise improves muscle tone but adds relatively little muscle mass to the female body These same considerations may also help to explain why thınness is more valuable to women than to men in the matıng market.

The job-market hypothesis and the mating-market hypothesis are equally consistent with evidence that middle- and upper-class American females become thinner than lower-class females only after puberty, which

\footnotetext{
${ }^{3}$ Anderson et al (1992) suggest that losing weight may be useful to women competing for economic success for a different reason because thinness inhibits ovulation and prevents pregnancies that would interfere with work This conclusion is not strongly supported by their data, however, and does not seem applicable to developed societies, where easier and more reliable birth control methods are readily avallable
} 
marks the approxımate begınnıng of serıous preparatıon for career competition as well as for mating competition Earlier in life the traditional positıve correlation between class and female fat prevalls (Garn and Clark 1976) ${ }^{4}$ Indeed, the two hypotheses seem entırely compatıble and might well be combined High socioeconomic status is advantageous in a female employee as well as in a wife, and hard work and high motivation are useful in a wife as well as in an employee Moreover, as two-income families become the middle- and upper-class norm, a wife with a successful career may be regarded more as an economic asset and a contribution to her husband's prestige than as a threat to his ego

\section{ADAPTIVE BEHAVIOR IN NOVEL CIRCUMSTANCES?}

I have suggested that the recent reversal in affluent modern societies of traditional class differences with respect to female fatness may be a biologically-mediated response to two novel circumstances chronic food surplus and the breakdown of barriers between men's and women's work These two developments have combıned, 1 propose, to make thınness helpful to women competıng for success in both the matıng market and the job market The hypothesis that biology may underly the reversal of class differences with respect to fatness has received very little attention, perhaps because it faces a formidable set of objections ${ }^{5}$

The most fundamental objection arises from the belief that human behavior is dominated by conscious choices that are vulnerable to social and cultural pressures, but immune to biological influence The answer, discussed briefly above, is that all behaviors of all organısms are subject to the same fundamental biological influence All behavior is produced by physiological and psychological mechanisms that evolved because they helped individuals to perpetuate their own genes, and this is as true of the most flexible and unpredictable human behavior as it is of the most automatic and stereotypic behavior of single-celled organisms

The belief that human culture is independent of human biology is often linked with the fallacious charge that any search for evolutionary origins supports the status quo by affirming that whatever evolved is natural and therefore superior, or fixed in genes and therefore immutable In fact, evolutionary science teaches the opposite behavior is that which gives individuals the flexibility necessary to respond differently to different circum-

\footnotetext{
${ }^{4}$ Sobal (1991) disagrees

'To the best of my knowledge, the hypothesis was first suggested by B S Low (1979a) and has been discussed in some detail only by C J Robbıns and S J C Gaulin in "Fat and Thın in Evolutionary Perspective"' (1988), an admirable presentation, whıch unfortunately has not been published It would have been cited frequently in the preceding pages if I had succeeded in obtaining a copy before this paper was completed and accepted Both Low, and Robbins and Gaulın focus on modern thinness as a signal of high socioeconomic status in the context of female competition for desirable mates
} 
stances Better understandıng of the relatıonship between a partıcular set of circumstances and behavioral choices is the goal of this paper, and such efforts can be as useful to those who would challenge the status quo as to those who would defend ${ }^{6}{ }^{6}$

Another set of objections focuses directly on fatness, thinness, and the biology of each One such objection is that the biology of human contours is dominated by thrifty physiological mechanısms evolved to favor fatness over thınness As we have seen above, however, thrifty mechanısms have always shared control with other mechanisms that favor thinness, sometimes by wasting calories, and the balance of power varies with circumstances

Another objection is that current standards of female beauty in the middle and upper classes conflict with the biological interests of women and their husbands Although obesity may shorten life and impair reproductive function, current beauty standards call for less than the optımum degree of female fatness in terms of both longevity and fertility (Brown 1988, Cassidy 1991)

Understanding of the relatıonshıp between fat and mortality is currently in a state of flux. The safest generalization seems to be that within a rather broad range of varıation, it doesn't make much difference Stını's review of the recent literature (1991) concludes that longevity is probably associated with moderate slenderness during youth and middle age combined with moderate obesity after age 60 In any case, more or less longevity late in life, after reproduction has ceased, has no effect on women's lifetıme fertılity It does, however, affect their ability to contribute to the reproductive success of younger relatives.

Although more fat than current beauty standards allow may be essental for optimal ovulatory function, pregnancy, and lactation, it is easy for all but the poorest women in developed societıes to gain weight quickly when they want to conceive, and almost impossible for them not to gain after they conceive Extreme slimness in young girls may delay the onset of ovulation, but this is not likely to affect completed fertility since first births in the upper social strata usually occur long after menarche On balance, it appears that the mortality and fertility effects of low female body fat in middle- and upperclass women are not likely to have great influence on inclusıve fitness, one way or the other

Still another objection is that competitive success in the matıng and job markets is more likely to reduce than to increase Darwınıan fitness The widespread assumption that fertility is inversely correlated with status and wealth in developed nations (Vınıng 1986) has been challenged, however, and there is considerable evidence to the contrary (Daly and Wilson 1983, Mueller and Short 1983, Essock-Vitale 1984, Gaulın 1986; Kaplan and Hill 1986; Turke 1989, 1990, Mueller 1991, Low and Clarke in press)

\footnotetext{
${ }^{6}$ I have been astonished by the extent to which work on this paper has increased both my awareness of and my liberation from the tendency to judge others by prevaling standards with respect to amount and distribution of body fat
} 
A better response is that inclusive fitness is best measured by gene survival in the long run rather than by more babies now (Kaplan and Hill 1986, Phılıpp and Seger 1989, Harpendıng and Rogers 1990, Rogers 1990. 1991, Turke 1990, Chisholm 1991, Low et al in press) It has long been recognized by evolutionary theorists that when fitness is determined manly by success in social competition with members of one's own species, slow and steady often wins the race That 15 , for those who have the means. investıng a lot in a few offspring is often a better strategy than investing a little in many offspring because it reduces intergenerational fitness variance and the risk of extınction (Seger and Brockmann 1987, Promislow and Harvey 1990)

When wealth is heritable, for example, the offspring of small families tend to be richer because their inheritance is divided into fewer portions, and because they are richer they are less likely to fall victım to the hazards of life that lead to complete reproductive fallure Rogers' model of this phenomenon suggests that "wealth is at least as good a predictor of long-term fitness as is immediate reproductive success." and that "selection may often favor economic motivations over reproductıve ones" (1990, pp 492-493) Long-term empirical data are scarce. but Mueller's study (1991) of the West Point class of 1950 found that professional success was the man determinant of reproductıve performance as measured by grandchildren as well as children

More good studies of the long-term relationship between status and fitness in the modern world are urgently needed Whatever that relationship turns out to be, all the evidence we have supports the conclusion that until recently, Darwınian inclusive fitness in humans has always been highly dependent on status and the resources that contribute to and are commanded by status (Betzig 1986, 1988) Socioeconomic status has been an especially powerful selective force in human evolution for several reasons Human status depends more on knowledge, alliances, and savings, which tend to grow over time, than on physical prowess, which begins to senesce at the age of first reproduction Humans are, therefore, one of the very few species in which status often rises throughout the life span In addition, wealth and status differences can be greater in humans than in other species because of the unique human ability to organıze extensıve coalıtıons and accumulate wealth Opportunities to use status and resources to contribute to the fitness of descendants and other relatives are much greater in humans because they often live for decades after they stop having babies, because they maintain bilateral and long-distance kinship ties, and because wealth and status are heritable (Rodseth et al 1991)

Taken together, these distınctive qualıtıes of human status make it clear that success in human social competition can contınue to benefit inclusive fitness in far-reachıng ways long after successful indıviduals have stopped making their own babies, and even after they have died (Turke submitted) This, in turn, means that fertılity is a very poor measure of human inclusive 
fitness, that the evolved propensity to compete for status and wealth may be adaptive even if it reduces fertılity, and that accurate measurement of human fitness will contınue to be difficult if not impossible

My hypothesis does not predict that female thinness will prove to be adaptive It does maintain that, in response to novel conditions, some women have adopted new behavior patterns (weight loss and weight control) in pursuit of an evolved propensity (competitıon for resources and status) that is far more ancient than the earliest hominids The new behavior will prove to be adaptive only if the propensity it serves contınues to be adaptıve (Turke 1990)

This implies that, when novel conditions are encountered, some behaviors are readıly modifiable in potentially adaptive directions, while others are likely to be relatively stable even if novel conditions make them maladaptive The major difference between behaviors that change in the face of new adaptive challenges and those that do not is likely to be that the latter are more fully controlled automatically, without conscious intervention, in the lower and older parts of the brain, while the former are more subject to conscious choice in the neocortex There is nothing profound in this suggestion, and it would hardly be useful to make were it not for the widespread belief, even among convinced Darwinısts, that since humans are stuck with behavioral mechanisms evolved in the distant past, there is no reason to expect them to behave adaptively in novel modern circumstances (Symons 1989, Tooby and Cosmides 1990)

Given the Darwinian assumption that all organisms have been designed by natural selection to cope with problems encountered in past environments, it is, however, hard to see how humans could invent potentially adaptive novel responses to novel circumstances, and pursue those responses even when they conflict with mechanisms evolved to cope with very different circumstances ${ }^{7}$ When individuals behave in potentially adaptive ways in what appear to be entirely novel circumstances, how can they know what to do? The most probable explanation is that they are responding to familiar but subtle cues that accompany the percelved novelty but have escaped the observer's attention (Tooby and Cosmides 1990)

The two apparent novelties at the center of this discussion are the avalability in modern developed societies of enough food to keep most people fat most of the time, and the breakdown of firm barriers between men's and women's work The ready avallability of surplus calories has been treated in the evolutionary literature mainly as an illustration of how radical cultural change combines with evolved traits to produce maladaptive results, in this

\footnotetext{
${ }^{7}$ That such flexibility may be found in other anımals is suggested by the contrast between the dispersed distribution, a social behavior, and absence of status competition among wild female chimpanzees (Goodall 1986, Wrangham and Smuts 1980) and the close cooperation and intense status competition exhibited by female chimpanzees when released from foraging constraints and forced to live in close proximity to others of both sexes in zoo enclosures (de Waal 1982, 1984, Baker 1992) Comparisons of the behavior of other anımals in the wild and in zoos might be instructive
} 
case, widespread obesity, particularly at the lower end of the socioeconomic scale While undoubtedly correct, this interpretation does not help to identify the process that has reversed class correlations and preferences with respect to female fatness

Chronic widespread food surplus is truly novel, but large variation over tıme and space in the frequency, severity, and predictability of food shortages has surely been typical of the human condition over its entire evolutionary history As the Venus of Willendorf and similar paleolithic figurines demonstrate, obesity is not a new phenomenon, and neither is starvation Since nutrition is basic to survival and reproduction, humans must have evolved numerous alternative strategies and associated decision rules cued by variation in food avalability (Beller 1977) When the threat of death or reproductive fallure from malnutrition is high. women have no choice but to concentrate on acquiring and conserving the energy needed for survival, ovulation, pregnancy, lactation, and child care, and men would be foolssh to prefer women who did not Natural selection controls, and leaves no independent scope for sexual selection When nutritional constraints are relaxed, however, so are the constraints on independent scope for sexual selection (Anderson 1988, p 320)

Women (and men) in traditional societıes spend much tıme. effort, and resources on a wide variety of body adornments that appear to function as conspicuous competitive displays of status and wealth (Low 1979a) "People like to modify their bodies We paint our faces, pierce nose or ears, circumcise the penis, enclose the neck, feet or waist in confinıng rings or shoes or corsets. bleach or brown or tattoo or even carve our flesh Often the entire body is the focus of modification" (Cassidy 1991, p 181) There is in principle, no reason that thinness could not be chosen by women to serve as a matıng stratagem when, as suggested above, chronic food surplus has made thinness rather than fatness the better sign of status and wealth

At the same time, male preference for wealthy, high status women as mates may well have been rising because of simultaneous changes in two other aspects of human sociality that are both ancient and selectively important One change is an increase in status variance among women because of increases in their earning power and property rights Another is the strong trend toward monogamous marriage and matıng in the upper social strata (Betzig 1986) which shifts the focus of male matıng effort from mate quantity toward mate quality (Trivers 1972)

The second apparent novelty that is central to this paper is the breakdown of barriers between men's and women's work This, too, is a genuine novelty that is, however, associated with at least one ancient and important aspect of human sociality Because much of the world's work has usually been done by women, sometımes most of it, women have a long history of copıng with intense economic competıtıon (Smuts 1991, Draper 1989) Demonstrating the capacity and the motivation for hard work is not a novel problem for human females The demonstration has usually been aimed at 
potential husbands, but there is in principle no reason that thinness should not be aimed at admissions officers and employers as well as at potential mates when food abundance makes thınness a reliable sıgn of persistence and effort

\section{INCIUSIVE FITNESS AND THE STUDY OF MODERN HUMAN BEHAVIOR}

Thıs has been a prelımınary and speculative effort to address the enıgma presented by recent changes in attitudes and behavior toward human body fat Regulation of human fatness is an extremely complex process that is still only dimly understood, and study of the mechanısms that produce adaptive flexibility in human behavior has barely begun Further study will surely change or refute much of what I have suggested I am less interested in defending the particular hypotheses of this paper than I am in advocatıng a point of view

Several of the disciplines that study aspects of human behavior-anthropology, psychology, and political science in particular-have made increasing (though still minor) use of evolutionary theory and methodology in recent years History is a conspicuous exception While Darwinists have begun to make use of historical data, historians have very nearly ignored Darwinism This is strange and unfortunate, for the two fields have much in common Evolutionary biology is the most historical of the sciences, natural history is its foundation Both fields deal with complex systems over time, often rely on narrative, and understand the impossibility of predicting the course of future events in complex systems

Darwinıan students of human behavior often argue that rapid cultural change has rendered much of modern human behavior anachronistic and maladaptive Some of it is, but sometımes humans are very good at finding adaptive solutions to problems that are significantly novel, without even knowing that that is what they are doing. This may well be the most distınctive of all human abilities Colınvaux has suggested that "the crucial thing settıng people apart from all other living things is their ability to change their nıche at will" (1978, p 219), which implies that novelty itself can be regarded as perhaps the greatest and most famıliar of human problems

Humans solve new kınds of problems in complex and mysterious ways involving obscure interactions among numerous physiological and psychological mechanısms and environmental cues whose existence we seldom suspect That we will ever understand in detall how we sometimes do it, and why we sometımes fall, is as probable or improbable as coming to understand in detall how the human mind works The one task is much the same as the other. We will understand more, sooner, if humanists and natural, social, and behavioral scientists all recognize that the human mind works in its uniquely human ways because it has been designed by natural 
selection to find adaptive solutions to the novel problems we ourselves create

My interest in the subject of this paper was aroused by $\mathrm{P} J$ Brown s recent article in Haman Nature on culture and the evolution of obesity (1991) Brown J L Anderson D M Buss and B S Low provided helpful comments on drafts of the paper and called my attention to important references Broun Anderson Lou $p$ Turke $S \mathrm{~J} C$ Gaulin and $J \mathrm{~S}$ Chisholm gave me access to unpublished paper, My thanks to all do not imply that any endorse my conclusions Alice Smuts and Barhara Smuts read questioned and commented on more dratts of this paper than I care to rememher

\section{REFERENCES}

Alexander R D The Bologi of Moral Sistems New York Aldine de Giuyter 1987

Anderson J L Breasts hips and buttocks revisited honest fatness for honest fitness thologs and Socubulogi 9(5) 319-324 1988

- Crauford C B Nadeau, J and Lindberg I Was the Duchess of Windsor right ' A cross-cultural review of the socsoecology of ideals of female body shape Lthologr and Soctobtologi 13(3) $197-227 \quad 1992$

Baley S M Absolute and relatuve sex differences in body composition In Seval Dimomphum in Homo Sapiens R L Hall (Ed) Neu York Praeger 1982 pp 363-390)

Baker. K C Herarch formation among captre female chmpanzees Lniversty of Michigan Ph D dissertation, 1992

Beller AS Fat and Thun a Natural Hotom of Ohesat Neu York Farral Straus and Gilloux 1977

Betzıg L Despotsmand Differential Reprodutom a Dam man Lien of Hostom New York Aldine 1986

- Matung and parenting in Darwinian perspective In Human Reproductue Behautor a Dan man Perspeane, L L Betzig M B Mulder and P W I urke(Eds) Cambridge Cambridge University Press, 1988 pp 3-20

Brown, P J Fatnes and fitness mpehistom and histon Paper presented at the annual meeting of the American Anthropological Associdion Phoenix AZ 18 November 1988

- Culture and the evolution of obesity Human Natue 2(1) $31-57 \quad 1991$

and Konner $M$ An anthropological perspective on obesity In Human Obestr R J Wurtman and J J Wurtman (Eds) Annals of the Nen York Academ of Setences 499 $29-46 \quad 1987$

Bruch. H The Golden Cage The Lntgma of Anotexa Newora, Cambrige MA Harvard University Press 1978

Brumberg J J Fasting Guls Cambridge. MA Hartard University Press 1988

Cahnman W J The stigma of obesity The Socwlogic al Quaterh 9(3) 283-299, 1968

Cassidy C M The good body when big is better Medual Anthopolog, 1343) 181-213 1991

Chisholm. J S Death hope and sex life histon theor and the deselopment of altematre seproductwe stratezies Paper presented at Wenner-Gren symposium The Politics of Reproduction 'Teresopolıs BraLil 1-9 November 1991

Colınvaux P The people s place In Whi Big Flence Antmak Ale Rale Princeton Princeton University Press. 1978 pp 212-233

Daly $M$ and Wilson. $M$ Set Evolution and Behaior second edition, Boston Willad Grant Press 1983

Draper P African marriage systems perspectives trom evolutionary ecology Lthologl and Soctobulogi 10(1-3) 145-169 1989

Essock-Vitale SM The reproductive success of wealths Ameicans Lthologt and Soctobotoes $5(1) \quad 45-49,1984$ 
Fallon, A E and Rozın, P Sex differences in perceptıons of ideal body shape Journal of Abnormal Psychology 94(1) 103-105, 1985

Garn, S M and Clark, DC Trends in fatness and the origın of obesity Pediatrics 57 443456,1976

- Sullivan, $T V$, and Hawthorne, V M The education of one spouse and the fatness of the other spouse Amencan Journal of Human Blology 1 223-228. 1989a

- Sullıvan, T V , and Hawthorne, V M Educational level, fatness, and fatness differences between husbands and wives Americ an Journal of Clinic al Nutrition 50 740-745. $1989 \mathrm{~b}$

Garner, D M , Garfinkel, P E , Schwartz, D , and Thompson, M Cultural expectations of thinness in women Psychological Reports 47 483-491, 1980

Gaulın, S J C Comment on D R Vining, Social vs reproductive success the central problem of human sociobiology Behavtoral and Brain Sciences 92191986

Goldblatt, P B . Moore, M E, and Stunkard. A J Social factors in obesity Journal of the American Medical Association 192(12) 1039-1044, 1965

Goodall J The Chimpanzees of Gombe Patterns of Behavior, Cambridge, MA Belknap Press, 1986

Goodman, W Decreasing our word power the new newspeak The New York Times Book Review, 27 Jan 1991, p 14

Hamilton, W D The evolution of social behavior Journal of Theorell al Biology 7 1-52, 1964

Harpending. $\mathrm{H}$ and Rogers, A R Fitness in stratıfied societies Ethologv and Soclobiolog, $11(6) 497-509,1990$

de Jonge, $\mathrm{P}$ The slugger nobody wanted The New York Times Magazine 5 April 1992 pp $20 \mathrm{ff}$

Kaplan, $\mathrm{H}$ and Hıll, $\mathrm{K}$ Sexual strategies and social class differences in fitness in modern industrial societies Behavtoral and Brain Sciences 9 198-201 1986

Low, B S Sexual selection and human ornamentation In Evolutionan Theor and Hitman Soctal Behavior. N Chagnon and $W$ Irons (Eds) Boston Duxbury, 1979a

- Environmental uncertainty and the parental strategies of marsupials and placentals American Naturalist 112 197-213, 1979b

- Sex, power and resources ecological and social correlates of sex differences Internatlonal Journal of Contemporary Soclology 27 45-71, 1990

- Sex. coalitions and politics in preindustrial societies Politics and Life Sciences 9(2) 6380,1992

- Alexander, R D , and Noonan, K M Human hıps, breasts and buttocks Is fat deceptive? Ethology and Soctobılogy 8(4) 249-257, 1987

- and Clarke, A L Resources and the life course patterns in the demographic transition Ethology and Soctoblologi, 13(5/6) 461-492, 1992

- Clarke, A L , and Lockridge, K A Toward an ecological demography Population and Development Review, 18(1) 1-31

Michie, J (translator) Epigrams of Martial, Harmondsworth Penguın, 1978

Mueller, E and Short, $\mathrm{K}$ Effects of income and wealth on the demand for children In Determinants of Fertiluty in Developing Countries. R A Bulatao and R D Lee (Eds) New York Academic Press, 1983 pp 590-642

Mueller, U Social and reproductive succers theoretical considerations and a case study of the West Point Class of 1950 Paper presented at the annual meeting of the Human Behavior and Evolution Society, Hamilton, Ontario, 23 August 1991

Philıppı, $\mathrm{T}$ and Seger $\mathbf{J}$ Hedging one's evolutionary bets revisited Trends in Ecologv and Evolution 4 41-44, 1989

Physician Task Force on Hunger in America Hunger in America The Grow'ing Epidemic, Boston, Harvard School of Public Health, 1985

Polivy, J , Garner, D M , and Garfinkel, P E Causes and consequences of the current preference for thin female physiques In Physical Appearance. Stigma and Social Behavior, C P Herman, M Zanna, and E T Huggıns (Eds) Hıllsdale Erlbaum, 1986, pp 89-112

Powdermaker, $\mathrm{H}$ An anthropological approach to the problem of obesity Bulletin of the New York Academy of Sciences 36 286-295, 1960

Promislow, D and Harvey, P Living fast and dying young a comparative analysis of lifehistory vanation among mammals Journal of Zoology $220 \quad 417-437,1990$ 
Ritenbaugh C Body size and shape a dialogue of culture and biology Medical Anthopologs 13(3) $173-180,1991$

Robbins. C. J and Gaulin. S J C Fat and then in evolutionary perspectwe Paper presented at the annual meeting of the Association for the Study of Food and Society, 27-29 May 1988

Rodseth L. Wrangham, R W, Harrigan, A M and Smuts, B B The human communty as a primate society Current Anthropologr 32(3) 221-254, 1991

Rogers A R Evolutionary economics of human reproduction Ethology and Socobiologr II(6) 479-495, 1990

- Conserving resources for children Human Nature 2(1) 73-82, 1991

Schamd S The Embarrassment of Ruches An Interpretation of Dutch Culture in the Golden Age New York, Knopf, 1987

Schwarts H Never Satisfied A Cultural Hostory of Diets, Fantaste' and Fat New York Free Press, 1986

Seger J and Brockmann, H J What is bet-hedging 'In Oxford Sur weus in Lvolutona viologr, P Harvey and L Partridge (Ed,) Oxford Oxford University Press, 1987, pp 182211

Seid, R P Never too Thin Why Women Are at War with thetr Bodies New York Prentice Hall, 1989

Smuts R W Women and Worh in America, New York Columbid University Press 1959

- The present also explains the past Ethology and Soctobologv 12 77-82, 1991

Sobal, J Obesity and socioeconomic status a framework for examining relationships between physical and social variables Medical Anthropology 13(3) 231-247, 1991

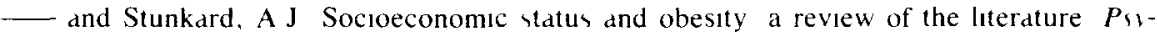
chological Bulletm 105 260-275, 1989

Stını, W A Body composition and longevity is there a longevous morphotype' Medical Anthropologv 13 215-229, 1991

Stuart K B and Jacobson, B Weight, Sex and Marrage A Delicate Balance, New York Norton, 1987

Symons, D A critique of Darwinian anthropology Ethology and Soclobrologi 10(1-3) 131144, 1989

Szekely, E A Never Too Thin, Toronto Women's Press 1988

Tooby, $\mathrm{J}$ and Cosmides $\mathrm{L}$ The past explains the present Ethologv and Socobology 1/(4/ 5) $375-424,1990$

Trivers, R L Parental investment and sexual selection In Sexual Selection and the Descent of Man. B Campbell (Ed) Chicago Aldine, 1972 pp 136-179

Soutal Evolutuon Menlo Park Benjamun/Cummms, 1985

Turke, P W Evolution and the demand for children Population and Development Revien 15 $61-90,1989$

- Which humans behave addatively, and why does it matter' Ethologi and Soctobiolog: $11 \quad 305-339,1990$

Evolution of the 100-year lifespan Submitted

Vining, D R Social versus reproductive success the central problem of human sociobiology Behalioral and Brain Suences 9 167-216, 1986

de Waal, F Chimpanzee Polith, New York Harper \& Row, 1982

- Sex differences in the formation of coditions among chimpanzees Ethology and Soctobiology 5(4) 239-255, 1984

Whiting, $\mathrm{M}$ A cross-cultural nutrition survey Harvard School of Public Health Ph D dissertatıon, 1958 (summarized in Brown and Konner, 1987)

Willams, G C Adaptation and Natural Selection, Princeton Princeton University Press, 1966

Wolf, N The Beauty Myth Hon' Images of Beautv Are Used Against Women New York Morrow, 1991

Wrangham, R and Smuts, B B Sex differences in the behavioral ecology of chımpanzees in the Gombe national park Journal of Reproduction and Fertilty Supplement 28 31,1980 